\title{
The effect of boric acid on penicillin induced experimental epilepsy
}

\section{Borik asidin penisilin ille indüiklenen deneysel epilepsi üzerine etkisi}

\author{
Mustafa Karademiir ${ }^{1}$, Gokhan Arslan²
}

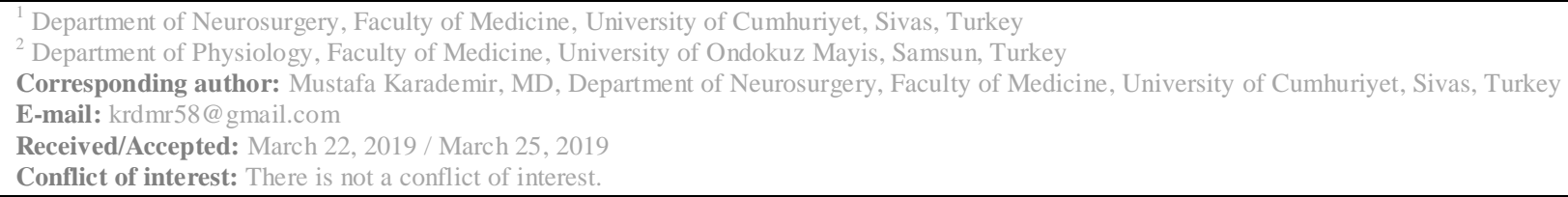

\begin{abstract}
SUMMARY
Objective: In daily life, people are exposed to a boron compound, boric acid. This study was designed to investigate the effect of different low doses of boric acid on penicillin-induced epileptiform activity. The role of boric acid in the anticonvulsant effect of gabapentin was also researched.

Method: Forty-eight Male Wistar rats were used in this study. After uretan anesthesia, rats were attached to a stereotaxic device. A bipolar electrode was fixed over the left somatomotor cortex for electrocorticography (ECoG) recordings. In the first set of experiments, $30 \mathrm{~min}$ after intracortical injection of penicillin (500 IU), four different doses of boric acid were received $(5,10,20$ and $40 \mathrm{mg} / \mathrm{kg}$ ) intraperitoneally (i.p.). In the second set of experiments, boric acid $(20 \mathrm{mg} / \mathrm{kg})$, gabapentin $(200 \mathrm{mg} / \mathrm{kg})$ and boric acid $(20 \mathrm{mg} / \mathrm{kg})+$ gabapentin $(200 \mathrm{mg} / \mathrm{kg})$ combination were administered. Electrocorticography recordings were persisted for 120 minutes after the drug injections and spike frequencies and amplitudes were calculated.

Results: Boric acid, at a dose of $5 \mathrm{mg} / \mathrm{kg}$, did not significantly change the means of spike frequency when compared to the control group. At the doses of 10,20 and $40 \mathrm{mg} / \mathrm{kg}$, boric acid showed proconvulsant activity by increasing the mean spike frequency in the 50,30 and 30 minutes, respectively. Gabapentin decreased the means of spike frequency in $30 \mathrm{~min}$. Boric acid $(20 \mathrm{mg} / \mathrm{kg})$ inhibited the anticonvulsant effect of gabapentin. No significant difference detected between any groups in terms of spike amplitude.

Conclusions: The results of the present study show that low doses of boric acid increase penicillin-induced seizures. We suggested that boric acid may show its proconvulsant effect probably via GAB Aergic pathway.

Keywords: Epilepsy, epileptiform activity, penicillin, boric acid, gabapentin
\end{abstract}

ÖZET

Amaç: Günlük hayatta insanlar, bir bor bileşiği olan borik aside maruz kalmaktadırlar. Bu çalışmada, düşük dozlarda uygulanan borik asidin penisilin kaynaklı epileptiform aktivite üzerindeki etkisini araştırdık. Ayrıca, borik asidin gabapentinin antikonvülsan etkisindeki rolünü de inceledik.

Yöntem: Bu çalışmada, kırk sekiz adet erkek Wistar sıçanı kullanıldı. Üretan anestezisinden sonra, sıçanlar stereotaksi aletine bağlandı. Elektrokortikografi kayıtları için sol somatomotor korteks üzerine bir bipolar elektrot sabitlendi. İlk deney setinde, intrakortikal penisilin (500 IU) enjeksiyonundan 30 dakika sonra, dört farklı borik asit dozu (5, 10, 20 ve $40 \mathrm{mg} / \mathrm{kg}$ ) intraperitoneal olarak uyguland1. İkinci deney setinde, borik asit $(20 \mathrm{mg} / \mathrm{kg})$, gabapentin $(200 \mathrm{mg} / \mathrm{kg}) \mathrm{ve}$ borik asit $(20 \mathrm{mg} / \mathrm{kg})+$ gabapentin $(200 \mathrm{mg} / \mathrm{kg})$ kombinasyonu uygulandı. İlaç enjeksiyonlarından sonra 120 dakika boyunca elektrokortikografi kayıtları kaydedildi ve sonrasında spike frekans ve amplitüdleri hesaplandı.

Bulgular: $5 \mathrm{mg} / \mathrm{kg}$ dozunda uygulanan borik asit, kontrol grubuyla karşılaştırıldığında spike frekansını anlamlı ölçüde değiştirmedi. 10, 20 ve $40 \mathrm{mg} / \mathrm{kg}^{\prime} 1 \mathrm{k}$ dozlarında uygulanan borik asit ise, sırasıyla 50., 30. ve 30. dakikalarda ortalama spike frekansını artırarak prokonvülsan aktivite gösterdi. Gabapentin 30. dakikadan sonra ortalama spike frekansını azaltt1. $20 \mathrm{mg} / \mathrm{kg}$ dozunda uygulanan borik asit, gabapentinin antikonvülsan etkisini inhibe etti. Spike amplüdü açısından hiçbir grup arasında anlamlı fark bulunmadı.

Sonuç: Bu çalışma, borik asidin düşük dozlarının penisilin kaynaklı nöbetleri arttırdığını göstermektedir. Borik asit, bu prokonvulzan etkisini muhtemelen GABAerjik sistem üzerinden göstermektedir.

Anahtar sözcükler: Epilepsi, epileptiform aktivite, penisilin, nöbet, gabapentin 


\section{INTRODUCTION}

According to World Health Organization, up to $10 \%$ of people have one seizure during their lifetime ${ }^{1}$. Seizures are typically seperated into two main categories: partial (focal) and generalized. Partial seizures affect one hemisphere of the brain and are the most recurring type of seizure seen in epileptic patients ${ }^{2}$. For the last 80 years, animal models have been the foundation on which many new therapies have been identified for the treatment of epilepsy. Animal models of epilepsy are necessary for developing new powerful antiepileptic drugs and exploration of the basic neuronal dysfunctions. The use of chemical convulsants such as penicillin, which blocks the inhibitory GABA system, provides guidance on new hypotheses regarding the mechanisms of human epilepsy ${ }^{3}$.

Boric acid, a trace element, is a boron compound that found in plants, animals, humans and some technological materials. It is dissolvable in water and can join into biochemical procedures ${ }^{4}$. In daily life, the richest sources of boric acid are fruits, vegetables, pulses, legumes and nuts. The daily average boron intake in the diet is assumed to be around $2 \mathrm{mg}$ per day ${ }^{5}$. Normally, boron is used to kill mites, insects, fungi and algae ${ }^{6}$. However, in some countries it have been used as a drug for vaginitis as fungicide ${ }^{7}$ or for wound healing ${ }^{8}$.

Previous studies have revealed that boric acid has toxic effects when applied at higher doses ${ }^{9}$, however it has protective effects at lower doses and it is also suggested that supplemental dietary boric acid is required for physiological processes ${ }^{10}$. Hunt reported that boric acid has protective effects against inflammatory and oxidative damage ${ }^{11}$. Furthermore, boric acid is involved in hormone metabolism, transmembrane signaling, and various enzymatic systems and acts as an antioxidant ${ }^{12}$. It has noted that boric acid decreases axonal and myelin damage in experimental sciatic nerve injury ${ }^{13}$.

While some case reports have shown that boric acid poisoning cause seizures ${ }^{8,}{ }^{14}$, there was no data showing the effects of boric acid on epileptic seizures at lower doses. Therefore in the present study, we aimed to investigate the effects of boric acid on penicillin-induced epileptic activity in rats, electrophysiologically. Furthermore, the role of boric acid in the effect of gabapentin, an antiepileptic drug which affects GABAergic pathway in brain, was also investigated.

\section{MATERIAL AND METHODS}

\section{Animals}

After experimental procedures were approved by the local ethics committee, male Wistar rats weighing 215-230 gr were obtained from The Animal House of Cumhuriyet University. Rats were housed in environmentally controlled conditions $\left(22-23{ }^{\circ} \mathrm{C}\right)$ on a $12 \mathrm{~h}$ light/dark cycle with free access to standart rat food and tap water. Rats were randomly separated into the following groups:

1. 500 IU penicillin $(2.5 \mu \mathrm{L}$, i.c. $)+$ sterile physiologic saline (1 mL, i.p.)

2. $500 \mathrm{IU}$ penicillin $(2.5 \mu \mathrm{L}$, i.c. $)+5 \mathrm{mg} / \mathrm{kg}$ boric acid (1 mL, i.p.)

3. $500 \mathrm{IU}$ penicillin $(2.5 \mu \mathrm{L}$, i.c. $)+10 \mathrm{mg} / \mathrm{kg}$ boric acid (1 mL, i.p.)

4. $500 \mathrm{IU}$ penicillin $(2.5 \mu \mathrm{L}$, i.c. $)+20 \mathrm{mg} / \mathrm{kg}$ boric acid (1 mL, i.p.)

5. $500 \mathrm{IU}$ penicillin $(2.5 \mu \mathrm{L}$, i.c. $)+40 \mathrm{mg} / \mathrm{kg}$ boric acid (1 mL, i.p.)

6. $500 \mathrm{IU}$ penicillin $(2.5 \mu \mathrm{L}$, i.c. $)+200 \mathrm{mg} / \mathrm{kg}$ gabapentin $(0,5 \mathrm{~mL}$, i.p.)

7. $500 \mathrm{IU}$ penicillin $(2.5 \mu \mathrm{L}$, i.c. $)+200 \mathrm{mg} / \mathrm{kg}$ gabapentin $(0,5 \mathrm{~mL}$, i.p. $)+20 \mathrm{mg} / \mathrm{kg}$ boric acid (1 mL, i.p.)

\section{$8.20 \mathrm{mg} / \mathrm{kg}$ boric acid (1 mL, i.p.)}

Each group composed of 6 rats.

\section{Electrocorticography (ECoG) Recordings}

Rats were anesthetized with urethane $(1.25 \mathrm{~g} / \mathrm{kg}$, i.p.) and put in a stereotaxic device. With reference to bregma three holes were opened with a drill (OmniDrill35, WPI, Korea) and two screws were placed over the left somatomotor cortex (positive coordinates: AP: $+4.0 \mathrm{~mm}$, LL: $3.0 \mathrm{~mm}$; negative coordinates: AP: $-4.0 \mathrm{~mm}$, LL: $3.0 \mathrm{~mm}$ ), and a reference screw was attached to right hemisphere (coordinates: AP: $-4.0 \mathrm{~mm}$, RL: 3.0 $\mathrm{mm})$. A tripolar electrode was wrapped around the screws and the electrode was connected to Powerlab recording system (PowerLab, 4/SP, AD Instruments, Castle Hill, NSW, Australia) by an isolated cable. ECoG activity was continually monitored with the help of the programme Labchart 7 Pro. The frequency and amplitude of the ECoG activity were measured off-line. Value $\%$ was calculated for each 10 minutes as the formula: Frequency Value $\%=$ (The mean of spike frequency after substance administered / 
The mean of spike frequency before substance administered) $\mathrm{x} 100$

\section{Drugs}

Sterile physiological saline, penicillin G potassium (I.E. Ulagay, Turkey), boric acid (99.5 $\%$ purity; Sigma Chemical Co., St. Louis, MO, USA) and gabapentin (Sigma Chemical Co., St. Louis, MO, USA) were used in experiments. All of the drugs were dissolved in Sterile physiological saline. Penicillin was injected using a Hamilton microsyringe (type $701 \mathrm{~N}$ ) and the needle stayed in place for a minute to hinder from backflow of the drug. A hole was opened for intracortical (i.c.) penicillin $\mathrm{G}$ injection. Penicillin $\mathrm{G}$ was injected through Hamilton microsyringe in a volume of $2.5 \mu \mathrm{l}$ into the cerebral cortex using stereotaxic device with the reference to bregma (coordinates AP: $-2.0 \mathrm{~mm}$, LL: $2.0 \mathrm{~mm}$, DV: -2 $\mathrm{mm}$ from the bone surface). Epileptic spike waves were seen approximately within 2 minutes after penicillin injection. The doses of boric acid $(5,10$, $20,40 \mathrm{mg} / \mathrm{kg})$, gabapentin $(200 \mathrm{mg} / \mathrm{kg})$ and boric acid $(20 \mathrm{mg} / \mathrm{kg})+$ gabapentin $(200 \mathrm{mg} / \mathrm{kg})$ were applied intraperitoneally after $30 \mathrm{~min}$ from penicillin injection and recordings were continued for 120 minutes. The dose of gabapentin was choosen according to the previous datas of researches ${ }^{16,17}$.

\section{Statistical analysis}

Statistical comparisons were made using the using SPSS software (ver. 22.0, IBM, Armonk, NY, USA). After the Kolmogorov-Smirnov normality test showed that the data from electrophysiological recordings was normally distributed, one-way analysis of variance (ANOVA) and Tukey-Kramer post hoc test was performed for multiple comparisons. The level of significance was set at $\mathrm{p}<0.05$.

\section{RESULTS}

Approximately within 2 minutes after penicillin (500 IU) administration spike waves started and the activity reached a constant level by 30 minutes. At this point, the drugs were injected and the experiments were ended after 2 hours. The means of the spike frequency and amplitude of the epileptiform activity before sterile physiological saline injection were $36.5 \pm 2.3$ spike/min and 937 $\pm 73 \mu \mathrm{V}$, respectively. In control group, $60 \mathrm{~min}$ after saline injection the means of spike frequency and amplitude were $39.4 \pm 4.6$ spike/min and 949 $\pm 65 \mu \mathrm{V}$, respectively (Fig. 1A).

Boric acid was administered $30 \mathrm{~min}$ after penicillin injection. Intraperitoneal administration of $5 \mathrm{mg} / \mathrm{kg}$ boric acid did not significantly change the means of spike frequency ( $>>0.05$ ) (Fig. 2A). Boric acid, at a dose of $10 \mathrm{mg} / \mathrm{kg}$ (i.p.) increased the mean frequency of the epileptiform activity between 50-100 $\mathrm{min}(\mathrm{p}<0.05)$ (Fig. 2A). At the doses of 20 and $40 \mathrm{mg} / \mathrm{kg}$, boric acid also showed proconvulsant activity and increased the means of spike frequency in $30 \mathrm{~min}$ for both doses (Fig. $2 \mathrm{~A})$. Due to there was no significant difference between the doses of 20 and $40 \mathrm{mg} / \mathrm{kg}$ of boric acid, $20 \mathrm{mg} / \mathrm{kg}$ dose was choosen for combination group. The means of spike frequency and amplitude of epileptiform activity were $59.8 \pm 5.9$ spike/min and $961 \pm 80 \mu \mathrm{V}$ in the 60 min after 20 $\mathrm{mg} / \mathrm{kg}$ boric acid administration, respectively (Fig. 1B).

$200 \mathrm{mg} / \mathrm{kg}$ gabapentin was used in the experiments. Gabapentin decreased the mean frequency and showed anticonvulsant activity in 30 min after injection $(\mathrm{p}<0.05)$ (Fig. 2B). The means of spike frequency and amplitude of epileptiform activity were $19.7 \pm 3.4$ spike/min and $892 \pm 59 \mu \mathrm{V}$ in the $60 \mathrm{~min}$ after $200 \mathrm{mg} / \mathrm{kg}$ gabapentin administration, respectively (Fig. 1C). Since the effects of both drugs were started at the same min, gabapentin and effective dose of boric acid $(20 \mathrm{mg} / \mathrm{kg}$ ) were administered at the same time. In combination group, boric acid inhibited the anticonvulsant effect of the gabapentin (200 $\mathrm{mg} / \mathrm{kg}$ ) (Fig. 2B). The means of spike frequency and amplitude of epileptiform activity were $51.8 \pm$ 5.6 spike/min and $929 \pm 67 \mu \mathrm{V}$ in the 60 min after boric acid + gabapentin injection, respectively (Fig. 1D).

There was no significant difference between any groups in terms of spike amplitude. No spike activity was observed before penicillin or after the injection of boric acid $(20 \mathrm{mg} / \mathrm{kg}$ ) alone (Fig. 1E). 
A) Control
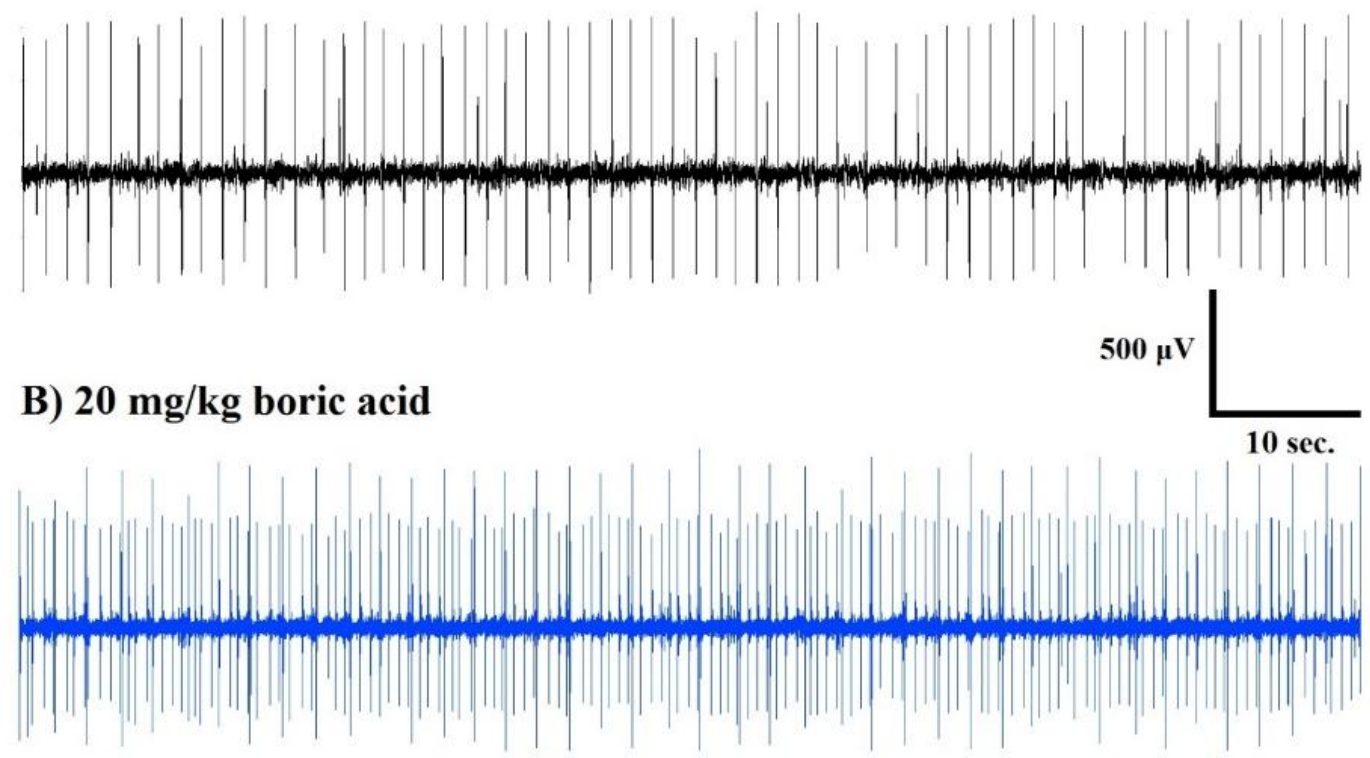

\section{C) $200 \mathrm{mg} / \mathrm{kg}$ gabapentin}

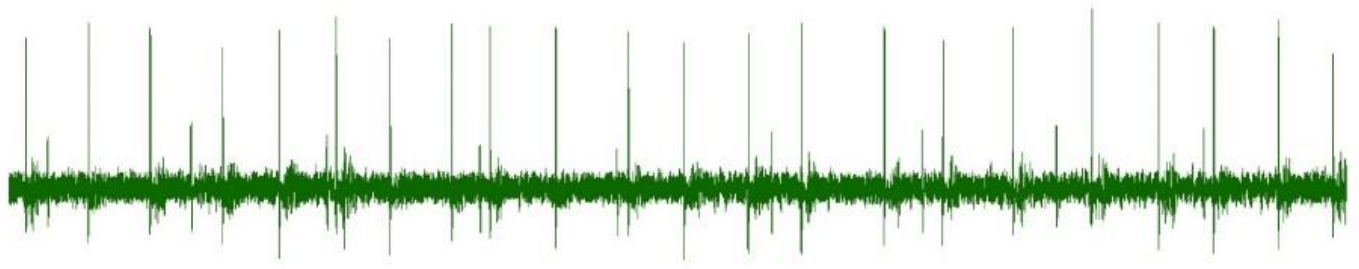

\section{D) $20 \mathrm{mg} / \mathrm{kg}$ boric acid $+200 \mathrm{mg} / \mathrm{kg}$ gabapentin}

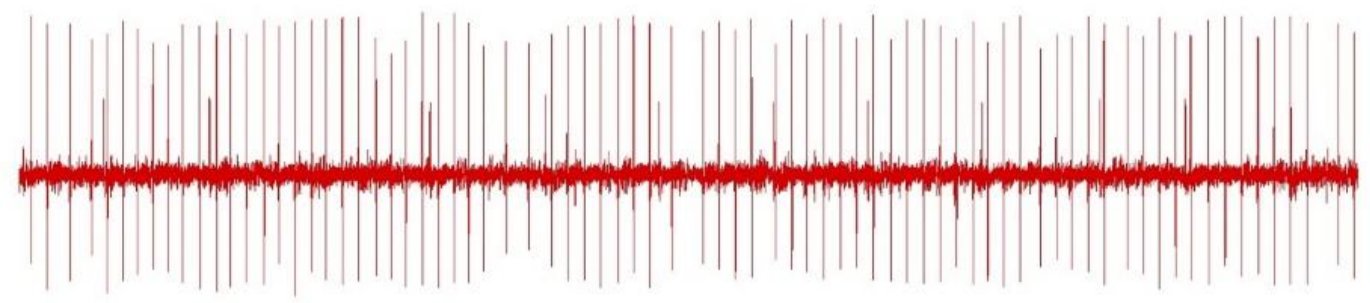

\section{E) Basal activity}

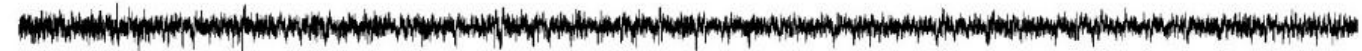

Figure 1. (A) The intracortical injection of penicillin (500 IU) induced epileptiform activity on ECoG. (B) Intraperitoneal administration of boric acid, at a dose of $20 \mu \mathrm{g} / \mathrm{kg}$ (i.p.) significantly increased the mean of frequency of epileptiform activity in the 30 min after injection without changing the amplitude. (C) Gabapentin, at a dose of 200 $\mathrm{mg} / \mathrm{kg}$ (i.p.), significantly decreased the mean of frequency of epileptiform activity in the 30 min after injection without changing the amplitude. (D) Administration of boric acid $(20 \mathrm{mg} / \mathrm{kg})$ inhibited the anticonvulsant activity of gabapentin $(200 \mathrm{mg} / \mathrm{kg}$ ). The combination showed proconvulsant activity only in 40 and $80 \mathrm{~min}$. (E) Baseline ECoG activity before penicillin or the injection of boric acid $(20 \mathrm{mg} / \mathrm{kg}$ ) without penicillin. Representative ECoGs are presented for the 60 min after boric acid or sterile physiological saline administration. 

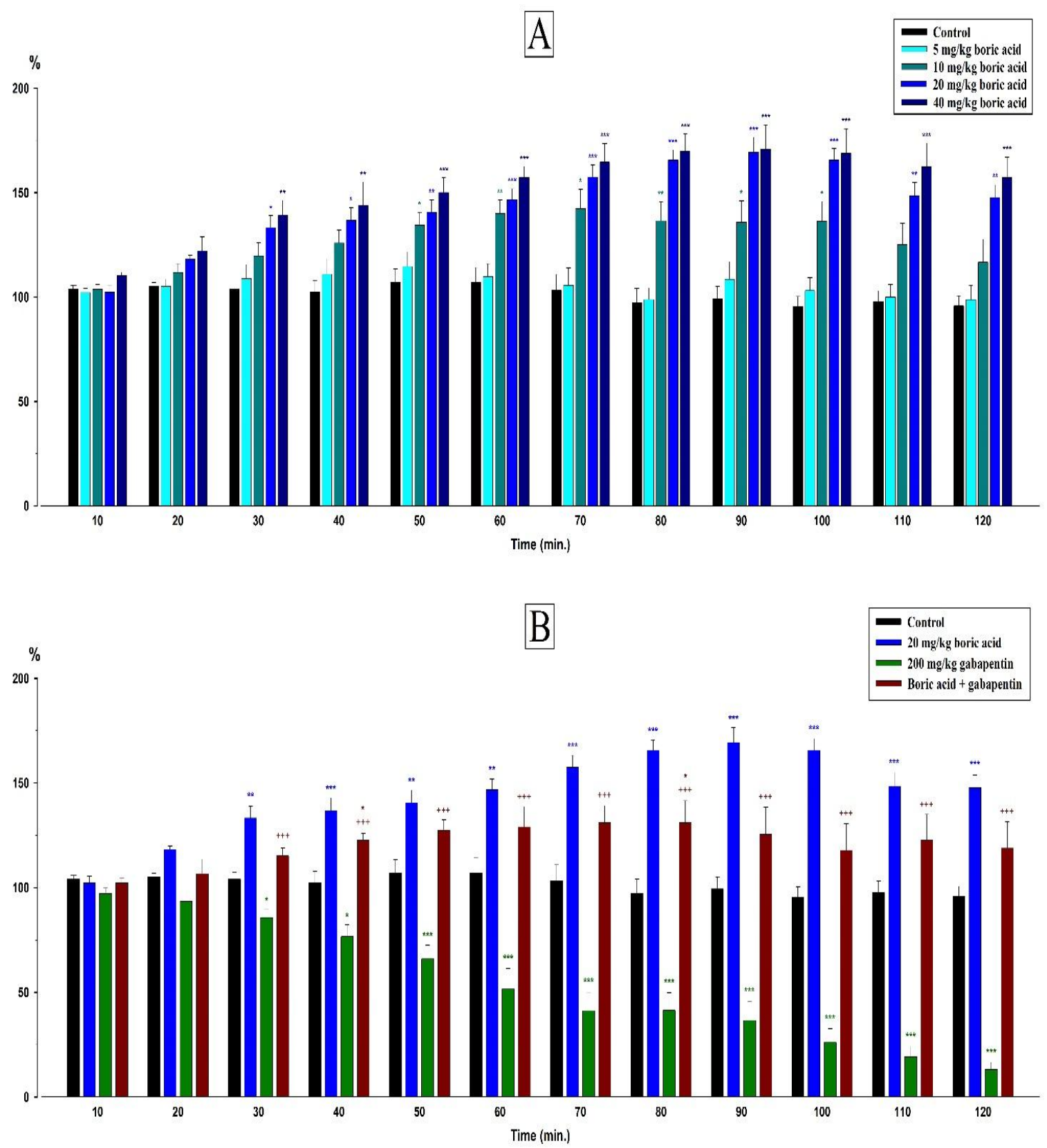

Figure 2. (A) The effects of intraperitoneal administration of different doses of boric acid $(5,10,20,40)$ on the mean spike frequency of penicillin-induced epileptiform activity. (B) The effects of intraperitoneal administration of gabapentin $(200 \mathrm{mg} / \mathrm{kg})$ and boric acid $(20 \mathrm{mg} / \mathrm{kg})+$ gabapentin $(200 \mathrm{mg} / \mathrm{kg})$ combination on the mean spike frequency of penicillin-induced epileptiform activity. ${ }^{*} \mathrm{p}<0.05 ; * * \mathrm{p}<0.01 ; * * * \mathrm{p}<0.001$ indicate significant differences compared to the control group. +++ $\mathrm{p}<0.001$ indicate significant difference compared to the gabapentin group. The percentage frequency of epileptiform ECoG activity value depends on both the frequency of epileptiform ECoG activity before and after the substance administered as it is defined as:

The mean of spike frequency after substance administered Frequency Value $\%=$

The mean of spike frequency before substance administered X 100 


\section{DISCUSSION}

In order to find the effect of boric acid on epileptiform activity, four doses of boric acid were administered $30 \mathrm{~min}$ after the penicillin injection. Intraperitoneal administration of boric acid shows proconvulsant activity without changing the spike amplitude. An antiepileptic drug gabapentin decreases the frequency of spike activies. When applied together, boric acid inhibited the anticonvulsant effect of gabapentin.

Boron is a trace element that is essential for the growth of many plants. Boron occurs most frequently in nature as borates and boric acid ${ }^{18}$. Humans consume about 2 miligrams of boric acid per day in nutrients ${ }^{5}$. Numerous laboratories using a variety of experimental models showed that boric acid cause toxic effects at the higher doses ${ }^{19-21}$. On the contrary, neuroprotective properties of boric acid were reported at lower doses of exposure 10, 20, 21 . Hacioglu et al. ${ }^{23}$ suggested that boric acid had potential neuroprotective effects against cellular damage produced by sodium floride. Furthermore, Kar et al. ${ }^{22}$ demonstrated that treatment with boric acid, at a dose of $25 \mathrm{mM}$, reduced the MDA levels, increased the NO levels, and decreased CAT activities. They suggest that boric acid had neuroprotective effects against ethanol-induced neurotoxicity as boric acid ${ }^{22}$. Çolak et al. ${ }^{10}$ showed that intraperitoneally given low dose of boric acid $(3.25 \mathrm{mg} / \mathrm{kg} / \mathrm{day})$ for 4 days protect brain against the pathological effects of aluminum chloride $(\mathrm{AlCl} 3)$. In contrast of these studies, the results of the present study confirm that intraperitoneal administration of boric acid, at the doses of $10 \mathrm{mg} / \mathrm{kg}$ and above, significantly increased the mean frequency of epileptiform activity without changing the amplitude. Çolak et al. ${ }^{10}$ noted that boric acid, at the doses of 36 and $58.5 \mathrm{mg} / \mathrm{kg} /$ day, does not prevent the rat brain from neurotoxicity and even increases neurotoxicity and at the end it causes cell death. When the literature is investigated, only this finding supports our data.

Gabapentin is a drug that used for the treatment of seizures and neuropathic pain. It is a derivative of the inhibitory neurotransmitter $\gamma$-aminobutyric acid (GABA) originally planned as a GABAmimetic agent that can freely penetrates the blood-brain barrier ${ }^{15}$. While, gabapentin is structurally similar to GABA, it does not bind to GABA receptors and is not converted to GABA ${ }^{24}$. Published researches suggested that gabapentin increased brain GABA levels by increasing the synthesis of $\mathrm{GABA}^{25}$ by non-vesicular release of
GABA ${ }^{26,27}$ and by preventing its metabolism ${ }^{28}$. In the present study, we used gabapentin at a dose of $200 \mathrm{mg} / \mathrm{kg}$. Borowizc et al. ${ }^{16}$ demonstrated that at a dose of $200 \mathrm{mg} / \mathrm{kg}$, gabapentin increased the electroconvulsive threshold from $6.1 \mathrm{~mA}$ to 16.2 $\mathrm{mA}$ in mice. Besides, ischemic acute seizures were reduced by intraperitoneal administration of gabapentin at $200 \mathrm{mg} / \mathrm{kg}$ and gabapentin reduced brain atrophy at the doses of 150 and $200 \mathrm{mg} / \mathrm{kg}$ but not at lower doses. In agreement with these studies, intraperitoneal administration of 200 $\mathrm{mg} / \mathrm{kg}$ gabapentin decreased the means of spike frequency within $30 \mathrm{~min}$ after injection and showed anticonvulsant activity in penicillin induced experimental epilepsy.

On the other hand, there has been only one study that showing the effect of boric acid on GABAergic activity ${ }^{29}$. Bicho et al. ${ }^{29}$ demonstrated that boric acid caused an anesthetic effect on enchytraeids and these soil intervertebrates did not able to escape the spiked soil. Gene expression results showed that boric acid increased $\mathrm{GABA}_{\mathrm{A}}$ receptor expression ${ }^{29}$. Up-regulation of $\mathrm{GABA}_{\mathrm{A}}$ receptors is explained as a result of initial non-competitively blocking of the ligand-gated $\mathrm{GABA}_{\mathrm{A}}$ receptor ion channels ${ }^{30}$. In the present study, boric acid inhibited the anticonvulsant effect of gabapentin. This result confirm that, there is a possible interaction between boric acid and GABAergic system. Further biochemical and molecular studies are needed to exactly prove these findings.

\section{CONCLUSION}

These data for the first time illustrate that nontoxic low doses of boric acid show proconvulsant activity in experimental epilepsy. Gabapentin decreases the means of spike frequency within 30 $\mathrm{min}$. Since the anticonvulsant effect of gabapentin is inhibited by the administration of boric acid, a physiological relation is suggested between boric acid and the GABAergic system in the model of experimental epilepsy.

\section{REFERENCES}

1. World Health Organization; Jan, 2009. Epilepsy Fact Sheet No 999. Available from: http://www.who.int/mediacentre/factsheets/fs 999/en/index.html.

2. Schachter SC. Seizure disorders. Med Clin North Am. 2009; 93(2):343-351.

3. Biziere K, Chambon JP. Animal models of epilepsy and experimental seizures. Rev. Neurol 1987; 143: 329-40.

4. Nielsen FH. Is boron nutritionally relevant? Nutr Rev. 2008; 66(4):183-91. 
5. Naghii MR, Wall PM, Samman S. The boron content of selected foods and the estimation of its daily intake among free-living subjects. J Am Coll Nutr 1996; 15(6):614-9.

6. Woods, WG. An introduction to boron: History, sources, uses and chemistry. Environ. Health Perspect 1994; 102: 5-11.

7. Sobel JD, Chaim W, Nagappan V, Leaman D. Treatment of vaginitis caused by Candida glabrata: Use of topical boric acid and flucytosine. Am J Obstet Gynecol 2003 Nov; 189(5): 1297-1300.

8. O'Sullivan K, Taylor M. Chronic boric acid poisoning in infants. Archives of Disease in Childhood, 1983; 58: 737-749.

9. International Programme on Chemical Safety, Environmental Health Criteria 204: Boron. WHO (World Health Organisation) 1998; Geneva, Switzerland.

10. Colak S, Geyikoglu F, Keles ON, Turkez H, Topal A, Unal B. The neuroprotective role of boric acid on aluminum chloride-induced neurotoxicity. Toxicology and Industrial Health 2011; 27(8) 700-710.

11. Hunt CD. Dietary Boron is a Physiological Regulator of the Normal Inflammatory Response. Trace Elem Man Anim. 2006; 233(March):1071-6.

12. Sogut I, Oglakci A, Kartkaya K, Ol KK, Sogut MS, Kanbak G, et al. Effect of boric acid on oxidative stress in rats with fetal alcohol syndrome. Exp Ther Med. 2015; 9(3):1023-27.

13. Kızılay Z, Erken HA, Çetin NK, Aktaş S, Abas Bİ, Y1lmaz A. Boric acid reduces axonal and myelin damage in experimental sciatic nerve injury. Neural Regen Res. 2016; 11(10):1660-5.

14. Gordon AS, Prichard JS, Freedman MH. Seizure disorders and anemia associated with chronic borax intoxication. Can Med Assoc J. 1973; 108(6):719-21.

15. Sills GJ. The mechanisms of action of gabapentin and pregabalin. Current Opinion in Pharmacology 2006; 6:108-113.

16. Borowicz KK, Swiader M, Luszczki J. Effect of gabapentin on the anticonvulsant activity of antiepileptic drugs against electroconvulsions in mice: An isobolographic analysis. Epilepsia 2002; 43(9): 956-963.

17. Comi AM, Traa BS, Mulholland JD, Kadam SD, Johnston MV. Gabapentin Neuroprotection and Seizure Suppression inImmature Mouse Brain Ischemia. Pediatr Res. 2008 Jul; 64(1): 81-85.
18. Pahl MV, Culver BD, Strong PL, Murray FJ, Vaziri ND. The effect of pregnancy on renal clearance of boron in humans: a study based on normal dietary intake of boron. Toxicol Sci 2001; 60:252-256.

19. Wong LC, Heimbach MD, Truscorr DR, et al. Boric acid poisoning: report of 11 cases. Can Med Assoc J.1964; 90: 1018-23.

20. Weir RJ, Fisher RS. Toxicologic studies on borax and boric acid. Toxicol Appl Pharmacol 1972; 23:351-364.

21. Hubbard SA. Comparative toxicology of borates. Biol Trace Elem Res 1998; 66:343357.

22. Kar F, Hacıŏlu C, Özkoç M, Üstünışık N, Bütün A, Uslu S, Kanbak G. The New Perspective Neuroprotective Effect Of Boric Acid Against Ethanol-Induced Oxidative Damage On Synaptosome. Journal of Applied Biological Sciences 2018; 12 (2): 28-33.

23. Hacioğlu C, Kar F, Sentürk H, Kanbak G. Neuroprotective effects of boric acid against fluoride toxicity on rat synaptosomes. Medical Science and Discovery 2018; 5(7):260-66.

24. Taylor CP, Gee NS, Su T-Z, Kocsis JD, Welty DF, Brown JP, Dooley DJ, Boden P, Singh L. A summary of mechanistic hypotheses of gabapentin pharmacology. Epilepsy Res 1998; 29:233-249.

25. Taylor CP, Vartanian MG, Andruszkiewicz R, Silverman RB. 3-alkyl GABA and 3alkylglutamic acid analogues: two new classes of anticonvulsant agents. Epilepsy Res 1992, 11:103-110.

26. Gotz E, Feuerstein TJ, Lais A, Meyer DK. Effects of gabapentin on release of gammaaminobutyric acid from slices of rat neostriatum. Arzneim-Forsch 1993; 43: 636638.

27. Honmou O, Kocsis JD, Richerson GB. Gabapentin potentiates the conductance increase induced by nipecotic acid in CA1 pyramidal neurons in vitro. Epilepsy Res 1995; 20:193-202.

28. Leach JP, Sills GJ, Butler E, Forrest G, Thompson GG, Brodie MJ: Neurochemical actions of gabapentin in mouse brain. Epilepsy Res 1997; 27:175-180.

29. Bicho RC, Gomes SI, Soares AM, Amorim MJ. Non-avoidance behaviour in enchytraeids to boric acid is related to the GABAergic mechanism. Environ Sci Pollut Res Int. 2015; 22(9): 6898-903.

30. Gong P, Guan X, Pirooznia M, Liang C, Perkins EJ. Gene expression analysis of CL20 -induced reversible neurotoxicity reveals 
GABA(A) receptors as potential targets in the earthworm Eisenia fetida. Environ Sci Technol 2012; 46:1223-1232. 